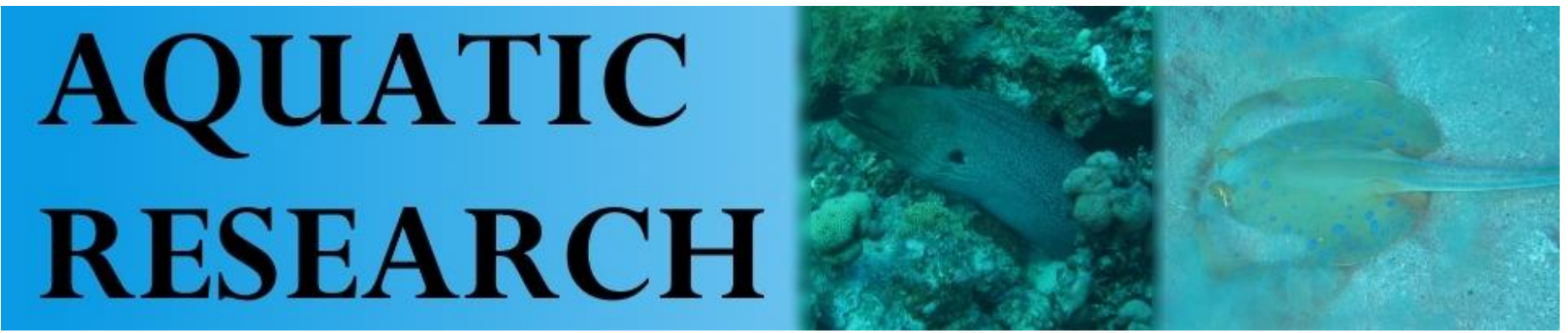

\title{
FILLETING YIELD, BODY CHARACTERISTICS AND LENGTH WEIGHT RELATIONSHIP OF FOUR FISH SPECIES FROM LOWER RIVER BENUE MAKURDI NIGERIA
}

\section{Simon Ihie Ikape ${ }^{1}$, Shola Gabriel Solomon²}

\section{Cite this article as:}

Ikape, S.I., Solomon, S.G. (2018). Filleting Yield, Body Characteristics and Length Weight Relationship of Four Fish Species from Lower River Benue Makurdi Nigeria. Aquatic Research, 1(3), 115-126. DOI: 10.3153/AR18013

Benue State University, Department of Biological Sciences, Centre for Food Technology and Research, Makurdi Nigeria

2 University of Agriculture, Department of Fisheries and Aquaculture, Makurdi, Nigeria

Submitted: 14.01 .2017

Accepted: 13.03.2018

Published online: 14.03.2018

Correspondence: Simon Ihie IKAPE

E-mail: ikapesimon@gmail.com

\section{ABSTRACT}

Fillet yield, length-weight relationship and condition factor of four commercial fish species including: Protopterus annectens, Labeo coubie, Auchenoglanis occidentalis and Mormyrus rume from lower river Benue Makurdi Nigeria were determined. A total of 600 fish samples were used, 50 individuals regarding each species for the period of three months. Fish samples were collected and transported to the University of Agriculture Makurdi, Department of Fisheries and Aquaculture laboratory where data were recorded on: The Total weight (TW), Total length (TL), Standard length (ST), Visceral weight (VW), Head length (HL), Weight of bones (WB), Weight of fins (WF) and Weight of fillet (WF) from the four fish species. Large differences in the fillet yield were observed among the species studied. Labeo cuobie had the highest fillet percentage yield $(65.51 \%)$ while Auchenoglanis occidentalis had the lowest fillet percentage yield (56.85\%). There was a linear relationship between fish length and fillet, also, significant correlation was found between fillet yield and body measurements (weight and length).

Keywords: Filleting yield, Physical characteristics, Fish species, River Benue, Condition factor 


\section{Introduction}

Study of characteristics of fish quality requirement and assessment indices are basic trade relations processes in deciding prosperity of commercial fisheries products. Therefore, study of fish products are deemed to be of paramount importance (El Tay, 1994). Processors, nutritionists and consumers, all have direct interest in the physical and chemical composition of fish. This can be done through the studying of general condition of fishes via studying their body weight, body length and filleting yield indices. This allows some flexibility in assessing the actual amount of fish tissue consumed and inedible parts discarded.

River Benue is the major tributary of the Niger River and it is approximately $1400 \mathrm{~km}$ long and is almost entirely navigable during the summer months. At this occasion, it is an important transportation route in the regions through which it flows.

It rises in the Adamawa Plateau of northern Cameroon, from where it flows west, and through the town of Garoua and Lagdo Reservoir, in to Nigeria south of the Mandara mountains, and through Jimeta, Ibi and Makurdi before meeting the Niger at Lokoja.

The river's largest tributary is the Mayo Kebbi, which connects it with the Logone River (part of the Lake Chad system) during floods. Other tributaries are Taraba River and River Katsina Ala. The river overflows its banks during the rainy season (May-October), but decreases drastically in volume leaving tiny island in the middle of the river during the dry season (November-April). The river contains several species of fresh water fishes of different families such as Protopteridae, Claroteidae, Mormyridae and family Cyprinidae. Little work has been done in these fish species concerning fish flesh quality, filleting yield and body weight characteristics particularly in River Benue. However, fragmented studies were done by a few researchers on these river namely Solomon and Akogu (2005), Olufeagba and Okomoda (2015) and Solomon et al., (2015), these researchers worked on the aspect of morphometric characteristics composition of some commercial fish species of the River Benue. The species studied included, Protopterus annectens, Labeo coubie, Auchenoglanis occidentalis and Mormyrus rume. The results of body weight composition and yield indices revealed clearly that the percentage decreased in the order of fillet, head, skeleton, viscera and skin for the most of studied fish species. Therefore, this study is designed to determine the fillet yield, length-weight relationship and condition factor of four commercial fish species from lower river Benue Makurdi Nigeria.

\section{Materials and Methods}

\section{Sampling Site}

The fish samples were collected from River Benue at Wadata Market, Makurdi the capital of Benue State, Nigeria, located at longitude $7^{\circ} 43^{\prime} \mathrm{N}$ and latitude $8^{\circ} 32^{\prime} \mathrm{E}$.

\section{Experimental Fish Species}

A total of 600 individuls, belonging to four families, were sampled for this study. These families include, Protopteridae, Claroteidae, Cyprinidae and Mormyridae. The studied fishes were represented by four species, namely, Protopterus annectens annectens, Labeo coubie, Auchenoglanis occidentalis and Mormyrus rume. Each species were composed of 50 samples each for the period of three months. The samples were collected fresh with cast and set net by the fishermen at landings area. The fish with crushed ice for preservation during assessment. The whole fresh samples were taken to the Department of Fisheries and Aquaculture laboratory Federal University of Agriculture Makurdi where their total and standard length were recorded (in $\mathrm{cm}$ ) using measuring rule (ruler) and total body weights were recorded in grams using an electronic weighing balance. The fishes were then filleted, eviscerated, beheaded using a sharp knife. The weight of viscera, fillets, heads, and skeletons (frames) were weighed separately using weighing balance. A pooled mean of these weights were calculated and used to estimate the percentage of each part of the dress out Fillets, head, gut and frame relative to the weight of whole fish.

\section{Data Collection}

Data were collected on: the total weight $(\mathrm{g})$, total Length $(\mathrm{cm})$, standard length $(\mathrm{cm})$, visceral weight $(\mathrm{g})$, head length $(\mathrm{cm})$, weight of bones $(\mathrm{g})$, weight of fins $(\mathrm{g})$ and weight of fillet $(\mathrm{g})$ from the four fish species.

\section{Statistical Analysis}

The data was analyzed using one way ANOVA statistical methods according to social science software (SPSS, version 17.0), followed by Duncan multiple range tests, and the difference between species was investigated by Independent sample $\mathrm{T}$ test Correlations between body size (weight and length) and fillet weight and yield were analyzed by Pearson's coefficient for linear regression (r). The differences were considered significant at $\mathrm{P}<0.05$. All data were expressed as mean \pm S.E.M 


\section{Results and Discussion}

Results from this study shows a significant variation in the mean, carcass composition and filleting yield indices of fish investigated. The fillet percentage was highest for the Labeo coubie $(65.51 \%)$ and lowest for Auchenoglanis occidentalis. (56.85\%). The highest filleting yield of Labeo coubie was due to small viscera $(5.63 \%)$ and skeleton $(8.27 \%)$ while the lowest filleting yield of Auchenoglanis occidentalis $s p$. was due to its large head, which measured (25.87 $\%)$. These results were in agreement with Eyo (1991), Abanu and Ikeme (1988) and Ali et al., (1992). Auchenoglanis occidentalis possessed large head $(25.87 \%)$ which had an adverse effect on the filleting yield of their bodies. Also there were some attributes, which were responsible for decreasing the filleting yield such as skeleton and fins in the case of Auchenoglanis occidentalis, which recorded 8.89\%, for skeleton and $3.69 \%$ for fins. Labeo coubie had moderate head and skeleton weights which resulted in the high filleting yield $(65.51 \%)$ among the studied fishes, although the head of the Labeo coubie was large and long compared to the rest of its components. This did not affect its filleting yield which was $(65.51 \%)$ because it had lower skeleton percentage $(8.27 \%)$.

Generally, the filleting yield of the studied fish species was a reflection of their anatomy i.e. species with large heads and skeleton relative to musculature give lower filleting yield than those with smaller heads and skeletons (Eyo, 1991; Ali et al., 1992). On the other hand, Auchenoglanis occidentalis had high inedible parts (head, skeleton and fins). These inedible parts are often discarded except for a few considerations where head, skeleton and gonads are used as by-products and sometimes used as diet for low-income people.

The edible parts (fillets) weight of studied fishes was very low when compared with fishes such as carp (53\%) and trout $(70 \%)(F A O, 1985)$. Since these inedible body components (head, skeleton, skin and viscera) are usually discarded except for a few considerations where heads and skeletons are eaten, the purchaser may thus suffer economic loss. Therefore, the use of such inedible parts for manufacture of fish silage or fish meal in different fisheries sectors is suggested. Length-weight relationships of fishes are often used to study the indication of fatness, general well-being or gonad development. It is also assumed that heavier fish of a given length are in better condition. Venu and Kurup (2003) noted that for an ideal fish, which maintain dimensional equality, the isometric value of $b$ would be 3 . The correlation coefficient was all positive and highly significant for $A$. occidentalis in River Benue which indicates that the length increases with increase in weight of the fish. This is in agreement with previous studies on different fish species from various water bodies (Layèyè, 2006), (Ayoade and Ikula, 2007). However, Shinkafi and Ipinjolu (2010) reported allometric growth pattern for A. occidentalis in River Rima, North-western Nigeria and consistent ' $b$ ' value for A. occidentalis in this study. Ikongbeh et al., (2012a) reported allometric growth pattern for B. docmac, from Lake Akata, Benue State, Nigeria. Isometric growth pattern was also reported for C. auratus. (Ikomi, and Odum, 1998). It was observed in the present study, that mean condition factor for $A$. occidentalis were less than ' 1 ' which indicates that the condition of the fish species can be improve, this implies that increase in length brought about little proportional increase in weight. Ikongbe et al., (2012b), reported similar observation in $C$. nigrodigitatus, and B. docmac from Lake Akata, Benue State, Nigeria. Condition factor is not constant for a species or population over a time interval and might be influenced by both biotic and abiotic factors such as feeding regime and state of gonadal development. There are also suggestions that fish condition can be influenced by certain extrinsic factors such as changes in temperature and photoperiod (Youson, et al., 1998). It was observed that the yield of fish was a reflection of its structural anatomy. Fish with small heads and viscera regardless of the season of spawning as in the case of Labeo coubie and Mormyrus rume produced a higher filleting yield than those with larger heads and viscera as in the case of Auchenoglanis occidentalis and Protopterus annectens. Auchenoglanis occidentalis had the height mean value of condition factor 0.88 and $\mathrm{R}^{2}$ value was 0.56 which indicates a negative allometric growth with the variation in the body weight correlating with changes in the length.

The length weight relationship of Protopterus annectens were as shown in figure 5, 6, 7 and 8 showed that the four fish species under this study exhibited negative allometric growth. This indicated that growth in length increase as weight increases and also the rate of increase in body length was not proportional to the increase in body weight. This result is different from the one obtained by Oniye et al., (2006) when he obtained the b-value for male and female P. annectens in Jachi dam, Nigeria to be 3.12 and 3.22 respectively. This could be due to the condition of the fish caught during different season, location, sex, sample site and nature of the water body. The regression coefficient of 0.83 compares favourably with the 0.86 and 0.84 obtained by Oniye et al., (2006) for Murmyrus rume. Fafioye and Oluajo (2005) also obtained a condition factor of 1.00 for some other fish species from Epe Lagoon. 


\section{Conclusion}

In conclusion, there was a higher correlation coefficient value in the length-weight relationship for all the fish species in this study. Also, yield of fish was a reflection of its structural anatomy. Fish with small heads and visceral regardless of the season of spawning as in the case of Labeo coubie and Mormyrus rume produced a higher filleting yield than those with larger heads and viscera as in the case of Auchenoglanis occidentalis and Protopterus annectens. Auchenoglanis occidentalis had the highest mean value of condition factor 0.88 and $\mathrm{R}^{2}$ value was 0.56 which indicates a negative allometric growth with the variation in the body weight correlating with changes in the length.

Table 1. Mean Percentage Carcass Composition and Fillet Yield of Four Fish Species from Lower Rive Benue.

\begin{tabular}{llllll}
\hline Body Characteristics & $\begin{array}{l}\text { Protopterus } \\
\text { annectens }\end{array}$ & $\begin{array}{l}\text { Auchenoglanis } \\
\text { occidentalis }\end{array}$ & Labeo coubie & Mormyrus rume & P-Value \\
\hline Total Weight $(\mathrm{g})$ & $270.31 \pm 14.81^{\mathrm{c}}$ & $211.34 \pm 12.85^{\mathrm{b}}$ & $158.04 \pm 10.00^{\mathrm{a}}$ & $169.18 \pm 11.81^{\mathrm{a}}$ & 0.00 \\
Total Length $(\mathrm{cm})$ & $42.85 \pm 1.24^{\mathrm{b}}$ & $29.87 \pm 0.85^{\mathrm{a}}$ & $28.97 \pm 0.75^{\mathrm{a}}$ & $30.03 \pm 1.05^{\mathrm{a}}$ & 0.00 \\
Standard Length $(\mathrm{cm})$ & $37.95 \pm 1.15^{\mathrm{b}}$ & $24.58 \pm 0.70^{\mathrm{a}}$ & $23.84 \pm 0.65^{\mathrm{a}}$ & $24.82 \pm 0.78^{\mathrm{a}}$ & 0.00 \\
$\%$ Visceral Weight $(\mathrm{g})$ & $13.57 \pm 0.39^{\mathrm{c}}$ & $6.41 \pm 0.34^{\mathrm{b}}$ & $5.63 \pm 0.23^{\mathrm{ab}}$ & $5.24 \pm 0.14^{\mathrm{a}}$ & 0.00 \\
$\%$ Weight of Head $(\mathrm{g})$ & $13.25 \pm 0.25^{\mathrm{a}}$ & $25.87 \pm 0.64^{\mathrm{c}}$ & $15.54 \pm 0.44^{\mathrm{b}}$ & $16.60 \pm 0.37^{\mathrm{b}}$ & 0.00 \\
& & & & \\
\% Weight of Fin $(\mathrm{g})$ & $1.24 \pm 0.10^{\mathrm{a}}$ & $3.69 \pm 0.15^{\mathrm{c}}$ & $2.40 \pm 0.09^{\mathrm{b}}$ & $2.26 \pm 0.11^{\mathrm{b}}$ & 0.00 \\
$\%$ Weight of Bone $(\mathrm{g})$ & $9.79 \pm 0.34^{\mathrm{c}}$ & $8.89 \pm 0.21^{\mathrm{b}}$ & $8.27 \pm 0.26^{\mathrm{b}}$ & $7.22 \pm 0.15^{\mathrm{a}}$ & 0.00 \\
& & & & \\
& & & & & \\
\end{tabular}

$*$ Mean in the same row with different superscripts differ significantly $(P<0.05)$ ( $\mathrm{a}, \mathrm{ab}, \mathrm{b}$, and $\mathrm{c}$ denote the levels of significant different)

Table 2. Body Characteristics of Selected Four Fish Species from Lower River Benue

\begin{tabular}{llllll}
\hline Body Characteristics & $\begin{array}{l}\text { Protopterus } \\
\text { annectens }\end{array}$ & $\begin{array}{l}\text { Auchenoglanis } \\
\text { occidentalis }\end{array}$ & Labeo coubie & Mormyrus rume & P-Value \\
\hline Total Weight & $270.31 \pm 14.81^{\mathrm{c}}$ & $211.34 \pm 12.85^{\mathrm{b}}$ & $158.04 \pm 10.00^{\mathrm{a}}$ & $169.18 \pm 11.81^{\mathrm{a}}$ & 0.00 \\
Total Length & $42.85 \pm 1.24^{\mathrm{b}}$ & $29.87 \pm 0.85^{\mathrm{a}}$ & $28.97 \pm 0.75^{\mathrm{a}}$ & $30.03 \pm 1.05^{\mathrm{a}}$ & 0.00 \\
Standard Length & $37.95 \pm 1.15^{\mathrm{b}}$ & $24.58 \pm 0.70^{\mathrm{a}}$ & $23.84 \pm 0.65^{\mathrm{a}}$ & $24.82 \pm 0.78^{\mathrm{a}}$ & 0.00 \\
Visceral Weight $^{\mathrm{a}}$ & $33.42 \pm 1.54^{\mathrm{c}}$ & $12.29 \pm 0.89^{\mathrm{b}}$ & $9.66 \pm 0.86^{\mathrm{ab}}$ & $8.38 \pm 0.58^{\mathrm{a}}$ & 0.00 \\
Head Length & $6.23 \pm 0.24^{\mathrm{b}}$ & $6.36 \pm 0.23^{\mathrm{b}}$ & $5.72 \pm 0.20^{\mathrm{b}}$ & $4.73 \pm 0.28^{\mathrm{a}}$ & 0.00 \\
Weight of Head & $37.90 \pm 2.65^{\mathrm{b}}$ & $55.07 \pm 3.73^{\mathrm{c}}$ & $22.91 \pm 1.26^{\mathrm{a}}$ & $25.95 \pm 1.63^{\mathrm{a}}$ & 0.00 \\
Weight of Fins & $3.54 \pm 0.34^{\mathrm{a}}$ & $7.28 \pm 0.48^{\mathrm{b}}$ & $3.56 \pm 0.23^{\mathrm{a}}$ & $3.84 \pm 0.32^{\mathrm{a}}$ & 0.00 \\
Weight of Bone & $28.70 \pm 2.42^{\mathrm{c}}$ & $18.21 \pm 1.13^{\mathrm{b}}$ & $12.70 \pm 0.82^{\mathrm{a}}$ & $13.51 \pm 1.05^{\mathrm{a}}$ & 0.00 \\
Fillet Weight & $161.84 \pm 8.91^{\mathrm{b}}$ & $119.81 \pm 7.97^{\mathrm{a}}$ & $107.93 \pm 7.03^{\mathrm{a}}$ & $114.57 \pm 8.44^{\mathrm{a}}$ & 0.00 \\
Condition Factor & $0.47 \pm 0.04^{\mathrm{a}}$ & $0.88 \pm 0.06^{\mathrm{c}}$ & $0.73 \pm 0.05^{\mathrm{b}}$ & $0.63 \pm 0.04^{\mathrm{b}}$ & 0.00 \\
Fillet Yield & $60.29 \pm 0.61^{\mathrm{b}}$ & $56.85 \pm 0.69^{\mathrm{a}}$ & $65.51 \pm 0.60^{\mathrm{c}}$ & $65.40 \pm 0.46^{\mathrm{c}}$ & 0.00
\end{tabular}

*Mean in the same row with different superscripts differ significantly $(P<0.05)$ ( $\mathrm{a}, \mathrm{ab}, \mathrm{b}$, and $\mathrm{c}$ denote the levels of significant different) 
Table 3. Correlation of the Body Characteristics of Protopterus annectens in Lower River Benue Makurdi.

\begin{tabular}{|c|c|c|c|c|c|c|c|c|c|c|}
\hline & TW & TL & SL & $\mathbf{V W}$ & HL & HW & WF & WB & WFL & $\mathbf{K}$ \\
\hline \multicolumn{11}{|l|}{ TW } \\
\hline $\mathrm{TL}$ & $0.603 *$ & & & & & & & & & \\
\hline SL & $0.649 *$ & $0.956^{*}$ & & & & & & & & \\
\hline VW & $0.862 *$ & $0.643^{*}$ & $0.672 *$ & & & & & & & \\
\hline HL & $0.713 *$ & $0.800 *$ & $0.835^{*}$ & $0.752 *$ & & & & & & \\
\hline HW & $0.935^{*}$ & $0.469 *$ & $0.511^{*}$ & $0.755^{*}$ & $0.600 *$ & & & & & \\
\hline WF & $0.636^{*}$ & $0.316^{*}$ & $0.279 *$ & $0.502 *$ & $0.383^{*}$ & $0.668 *$ & & & & \\
\hline WB & $0.853^{*}$ & $0.355^{*}$ & $0.395^{*}$ & $0.673^{*}$ & $0.488^{*}$ & $0.950 *$ & $0.602 *$ & & & \\
\hline WFL & $0.973 *$ & $0.614 *$ & $0.661 *$ & $0.840^{*}$ & $0.712 *$ & $0.862 *$ & $0.600 *$ & $0.742^{*}$ & & \\
\hline K & -0.160 & $-0.636^{*}$ & $-0.618^{*}$ & $-0.233^{*}$ & $-0.430 *$ & -0.123 & -0.062 & -0.065 & -0.143 & \\
\hline FY & -0.020 & -0.032 & -0.014 & -0.049 & -0.065 & $-0.161 *$ & --0.043 & $-0.282 *$ & $0.175^{*}$ & $0.217 *$ \\
\hline
\end{tabular}

*Correlation significant at $P<0.05$

KEY: TW= Total Weight, TL=Total Length, SL=Standard Length, VW=Visceral Weight, HL= Head Length, HW=Weight of Head (g), $\mathrm{WF}=$ Weight of Fins, WB=Weight of Bones, K Condition Factor, WFL=Fillet Weight.

Table 4. Correlation of the Body Characteristics of Mormyrus in River Benue Nigeria.

\begin{tabular}{|c|c|c|c|c|c|c|c|c|c|c|}
\hline & TW & TL & SL & VW & HL & HW & $\mathbf{W F}$ & WB & WFL & $\mathbf{K}$ \\
\hline \multicolumn{11}{|l|}{ TW } \\
\hline TL & $0.929 *$ & & & & & & & & & \\
\hline SL & $0.888^{*}$ & $0.976^{*}$ & & & & & & & & \\
\hline VW & $0.925^{*}$ & $0.877^{*}$ & $0.850 *$ & & & & & & & \\
\hline HL & $0.876^{*}$ & $0.829 *$ & $0.772 *$ & $0.821^{*}$ & & & & & & \\
\hline HW & $0.955^{*}$ & $0.906^{*}$ & $0.878^{*}$ & $0.900^{*}$ & $0.812^{*}$ & & & & & \\
\hline WF & $0.835^{*}$ & $0.700 *$ & $0.676^{*}$ & $0.731 *$ & $0.688^{*}$ & $0.790 *$ & & & & \\
\hline WB & $0.973^{*}$ & $0.909 *$ & $0.863^{*}$ & $0.912 *$ & $0.890 *$ & $0.904 *$ & $0.753^{*}$ & & & \\
\hline WFL & $0.977 *$ & $0.919^{*}$ & $0.877 *$ & $0.911 *$ & $0.885^{*}$ & $0.932 *$ & $0.837 *$ & $0.976^{*}$ & & \\
\hline K & $-0.237 *$ & $-0.448^{*}$ & $-0.451 *$ & $-0.247^{*}$ & $-0.309^{*}$ & $-0.210^{*}$ & 0.012 & $-0.247 *$ & $-0.239 *$ & \\
\hline FY & $0.487 *$ & $0.442 *$ & $0.452 *$ & $0.373^{*}$ & $0.456^{*}$ & $0.296^{*}$ & $0.441 *$ & $0.506^{*}$ & $0.542 *$ & -0.138 \\
\hline
\end{tabular}

*Correlation significant at $P<0.05$

KEY: TW= Total Weight, TL=Total Length, SL= Standard Length, VW=Visceral Weight, HL= Head Length, WH=Weight of Head, WF=Weight of Fins, WB=Weight of Bones, K Condition Factor, WFL=Fillet Weight. 
Table 5. Pearson Correlation of the Body Characteristics of Auchenoglanis occidentalis in River Benue Nigeria

\begin{tabular}{|c|c|c|c|c|c|c|c|c|c|c|}
\hline & TW & TL & SL & $\mathbf{V W}$ & HL & HW & $\mathbf{W F}$ & WB & WFL & $\mathbf{K}$ \\
\hline \multicolumn{11}{|l|}{ TW } \\
\hline TL & $0.769 *$ & & & & & & & & & \\
\hline SL & $0.729 *$ & $0.957 *$ & & & & & & & & \\
\hline VW & $0.812 *$ & $0.654 *$ & $0.636^{*}$ & & & & & & & \\
\hline HL & $0.622 *$ & $0.666^{*}$ & $0.610 *$ & $0.439 *$ & & & & & & \\
\hline HW & $0.903^{*}$ & $0.586^{*}$ & $0.567 *$ & $0.710^{*}$ & $0.507^{*}$ & & & & & \\
\hline WF & $0.794 *$ & $0.565^{*}$ & $0.536^{*}$ & $0.766^{*}$ & $0.442 *$ & $0.726^{*}$ & & & & \\
\hline WB & $0.939 *$ & $0.723^{*}$ & $0.696^{*}$ & $0.763^{*}$ & $0.612 *$ & $0.820 *$ & $0.760 *$ & & & \\
\hline WFL & $0.929 *$ & $0.757^{*}$ & $0.712 *$ & $0.723^{*}$ & $0.590^{*}$ & $0.766^{*}$ & $0.689 *$ & $0.876^{*}$ & & \\
\hline K & -0.065 & $-0.509 *$ & $-0.526^{*}$ & -0.102 & $-0.249 *$ & 0.030 & 0.002 & -0.056 & -0.103 & \\
\hline FY & -0.062 & 0.122 & 0.134 & -0.148 & -0.033 & $-0.326^{*}$ & -0.139 & -0.059 & 0.121 & -0.271 \\
\hline
\end{tabular}

KEY: TW= Total Weight, TL=Total Length, SL=Standard Length, VW=Visceral Weight , HL= Head Length, WH=Weight of Head, WF=Weight of Fins, WB=Weight of Bones, $\mathrm{K}$ Condition Factor, WFL=Fillet Weight

Table 6. Pearson Correlation of the Body Characteristics of Labeo coubie in River Benue Nigeria

\begin{tabular}{|c|c|c|c|c|c|c|c|c|c|c|}
\hline & TW & TL & SL & VW & HL & HW & WF & WB & WFL & $\mathbf{K}$ \\
\hline TW & & & & & & & & & & \\
\hline TL & $0.692 *$ & & & & & & & & & \\
\hline SL & $0.674 *$ & $0.973 *$ & & & & & & & & \\
\hline VW & $0.898 *$ & $0.495^{*}$ & $0.459^{*}$ & & & & & & & \\
\hline HL & $0.622 *$ & $0.906^{*}$ & $0.907 *$ & $0.379 *$ & & & & & & \\
\hline HW & $0.959 *$ & $0.706^{*}$ & $0.681 *$ & $0.912 *$ & $0.646^{*}$ & & & & & \\
\hline WF & $0.904 *$ & $0.584 *$ & $0.546^{*}$ & $0.856^{*}$ & $0.520 *$ & $0.894^{*}$ & & & & \\
\hline WB & $0.962 *$ & $0.681^{*}$ & $0.652 *$ & $0.899 *$ & $0.616^{*}$ & $0.952 *$ & $0.880 *$ & & & \\
\hline WFL & $0.985^{*}$ & $0.719 *$ & $0.714^{*}$ & $0.861 *$ & $0.668^{*}$ & $0.937^{*}$ & $0.881^{*}$ & $0.940 *$ & & \\
\hline $\mathrm{K}$ & 0.047 & $-0.439 *$ & $-0.423^{*}$ & 0.092 & $-0.328 *$ & -0.019 & 0.080 & -0.019 & 0.031 & \\
\hline FY & $0.294^{*}$ & $0.343 *$ & $0.399 *$ & 0.044 & $0.386^{*}$ & 0.159 & 0.136 & 0.133 & $0.394 *$ & $0.188^{*}$ \\
\hline
\end{tabular}

KEY: TW= Total Weight, TL=Total Length, SL=Standard Length, VW=Visceral Weight , HL= Head Length, WH=Weight of Head, WF=Weight of Fins, WB=Weight of Bones, $\mathrm{K}$ Condition Factor, WFL=Fillet Weight 


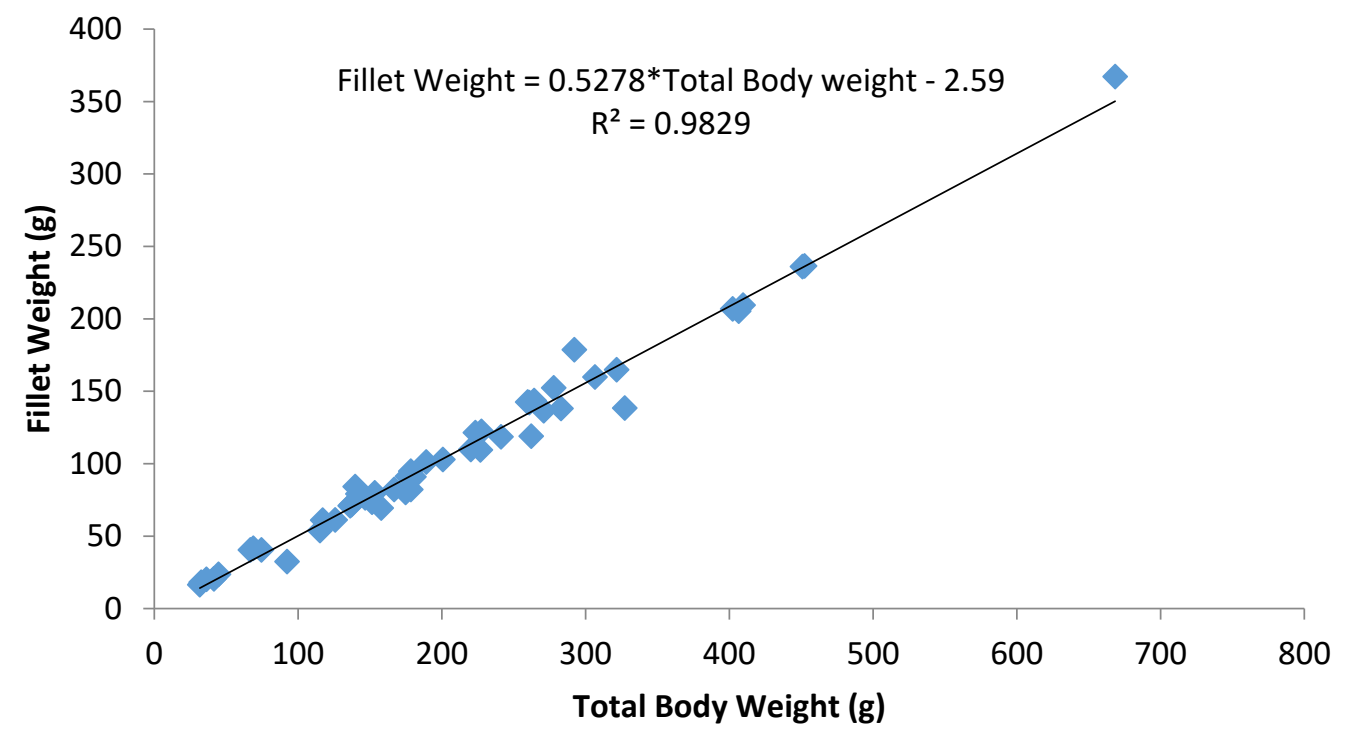

Figure 1. Body Weight and Fillet Yield Relationship of Auchenoglanis occidentalis from River Benue

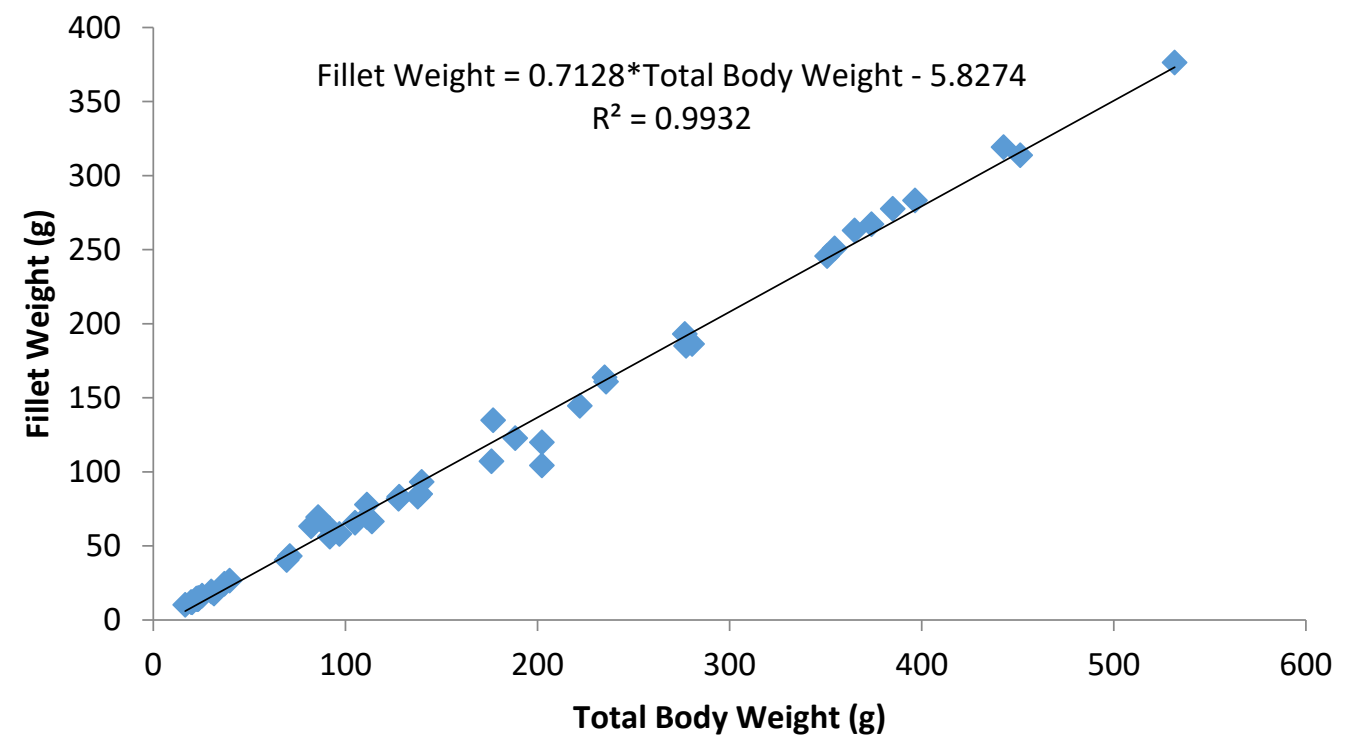

Figure 2. Body Weight and Fillet Yield Relationship of Mormyrus rume from River Benue 


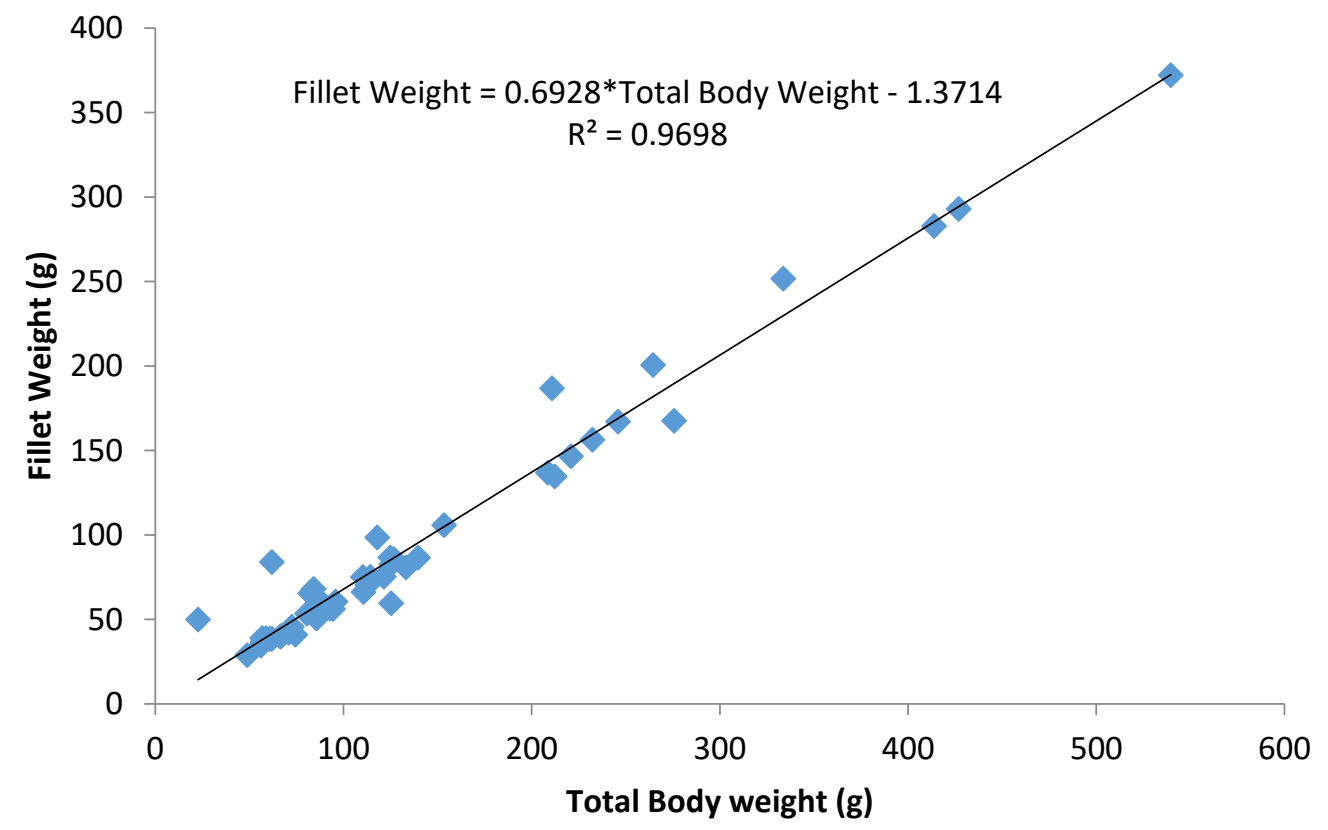

Figure 3. Body Weight and Fillet Yield Relationship of Labeo coubie from River Benue

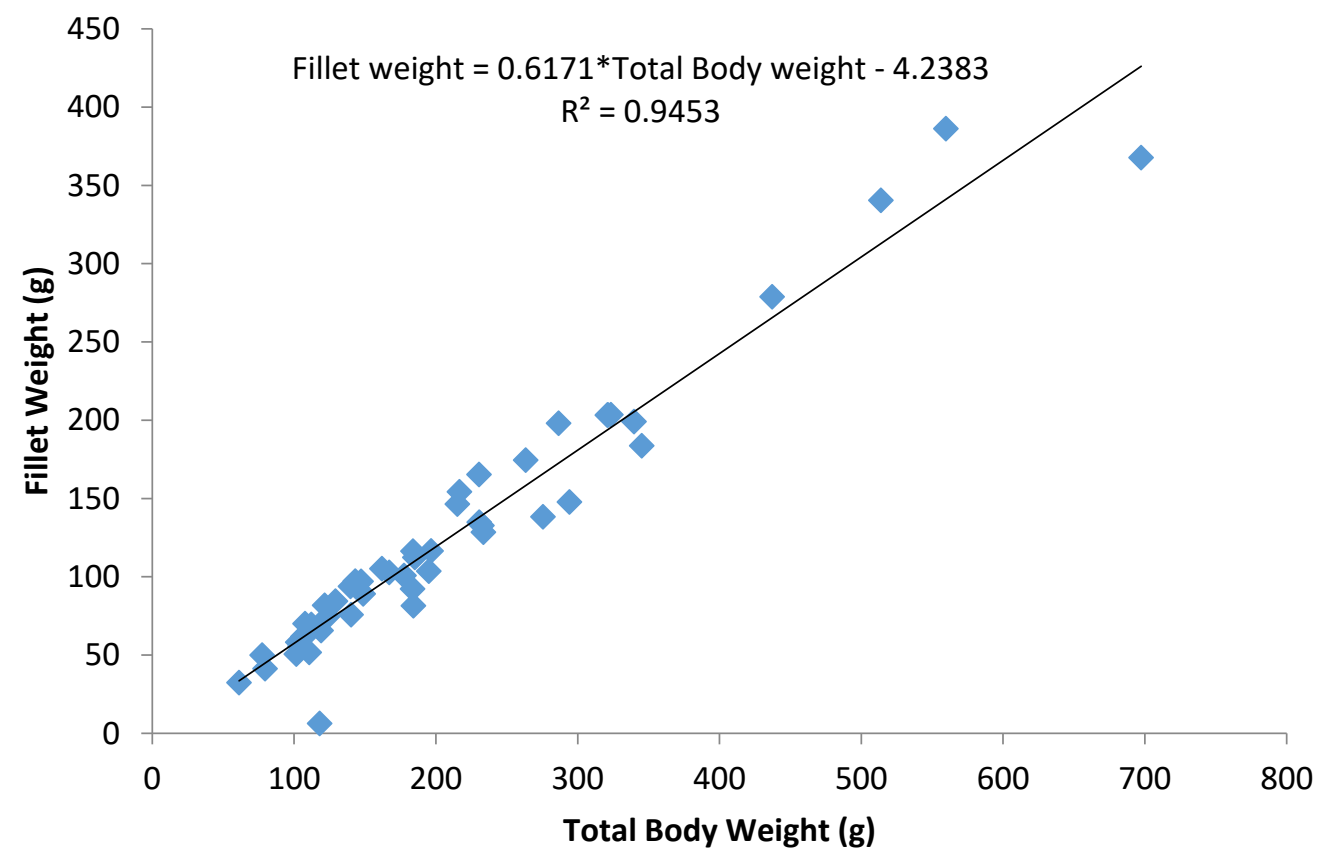

Figure 4. Body Weight and Fillet Yield Relationship of Proptopterus annectens from River Benue 


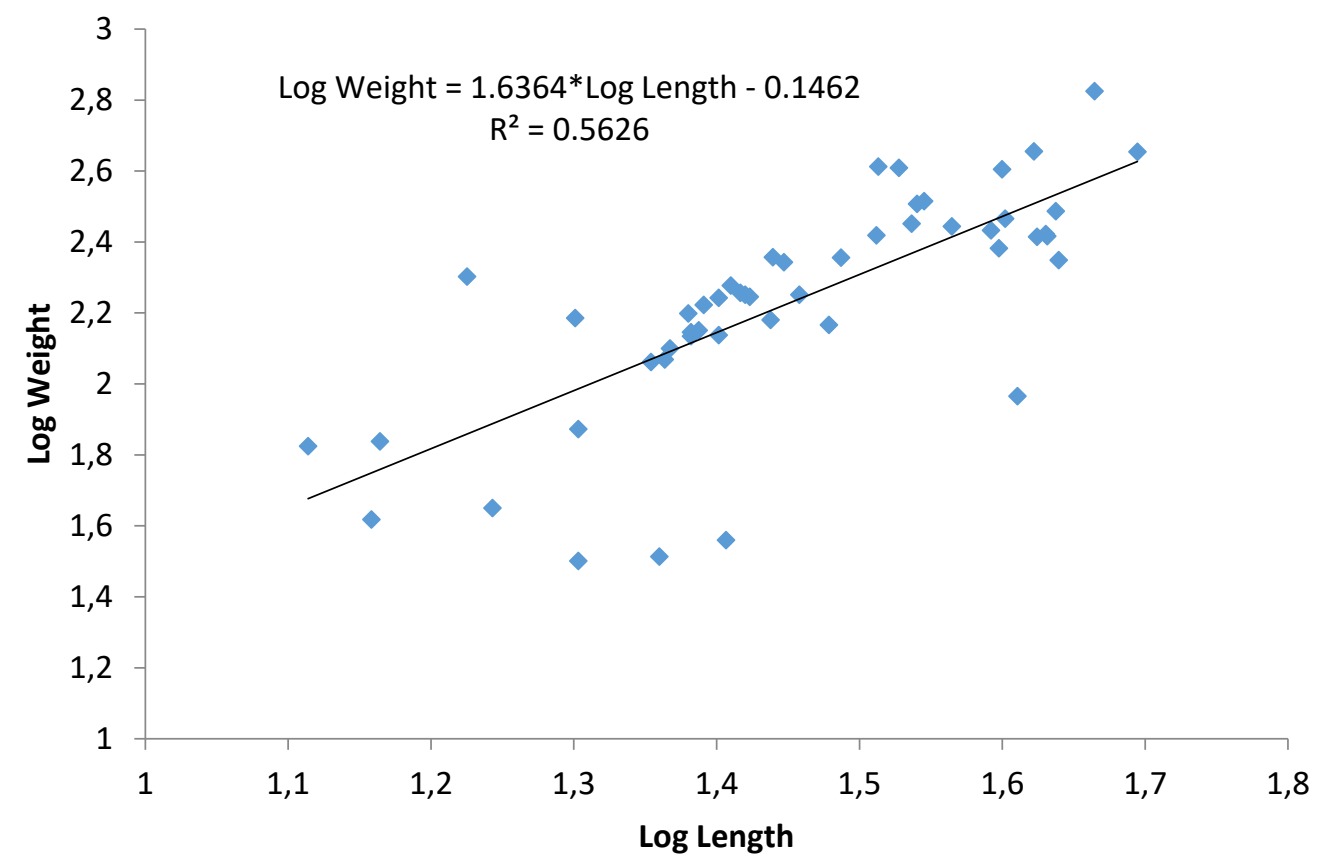

Figure 5. Length-Weight Relationship of Auchenoglanis occidentalis from Lower River Benue

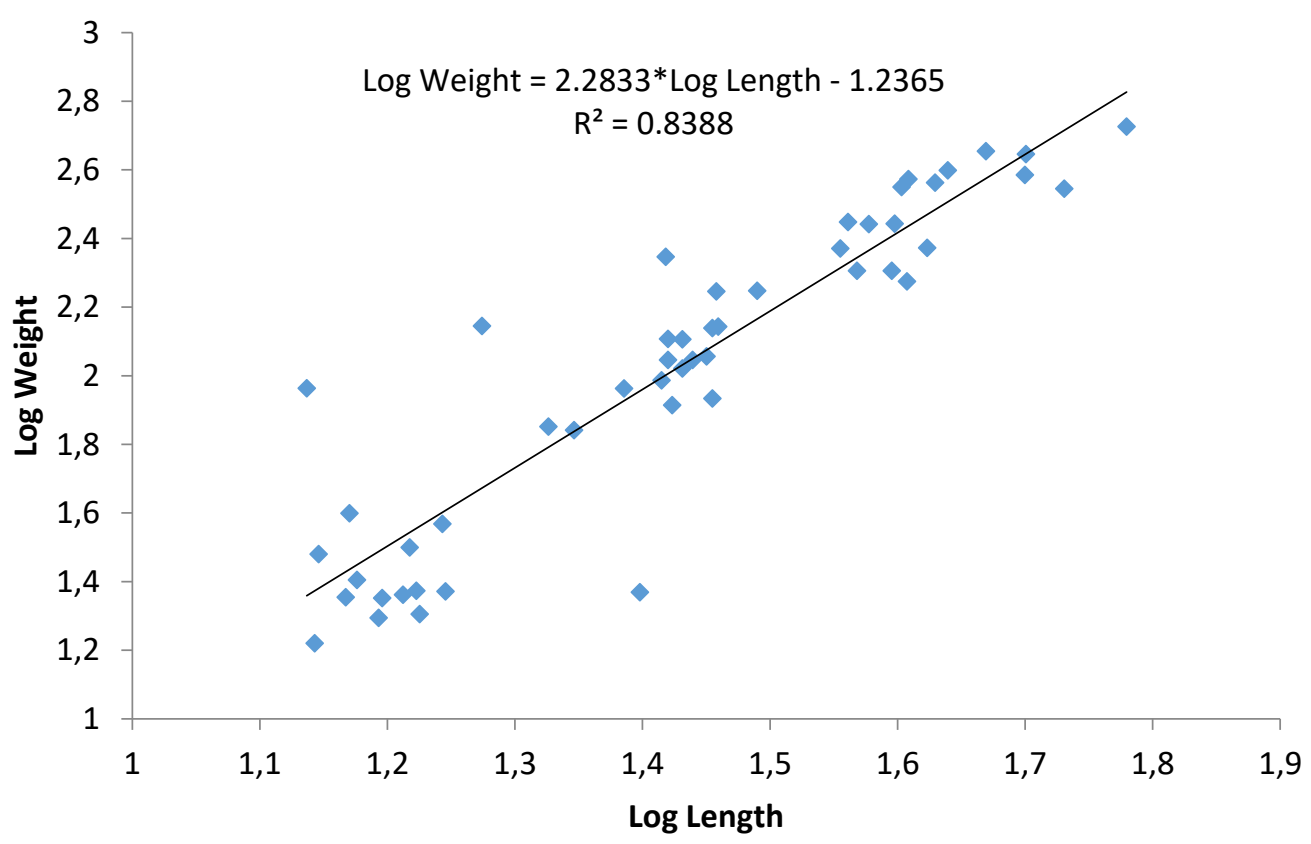

Figure 6. Length-Weight Relationship of Mormyrus rume from Lower River Benue 


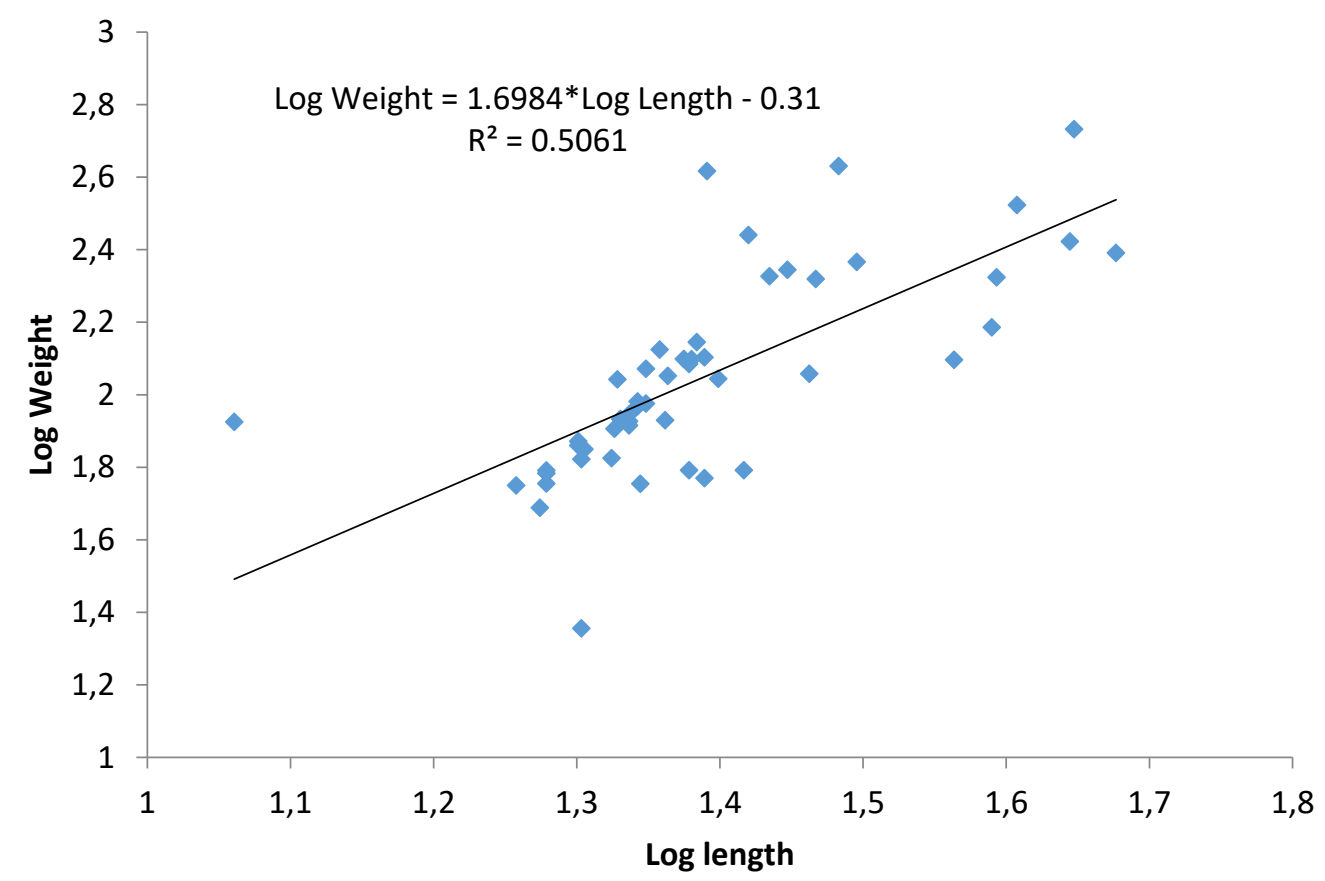

Figure 7. Length-Weight Relationship of Labeo coubie from Lower River Benue

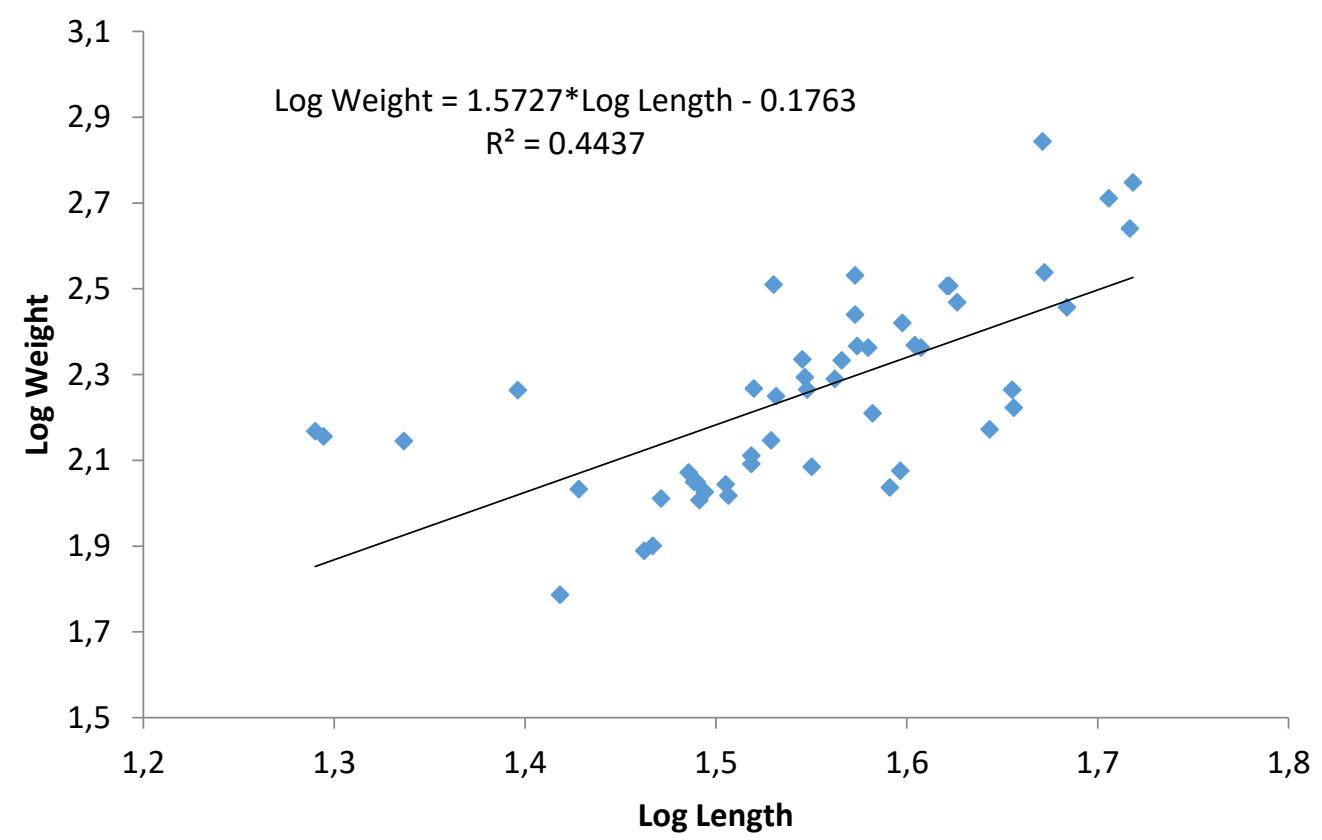

Figure 8. Length-Weight Relationship of Protopterus annectens from Lower River Benue 


\section{References}

Abanu, D.O., Ikeme R.G. (1988). Prediction of fillet weight, fillet yield and fillet fat for live river catfish (Pangasianodon hypophthalmus). Aquaculture, 288, 166-171.

Allen, P. (1993). Effects of acute exposure to cadmium (II) chloride and lead (II) chloride on the hematological profile of Oreochromis aureus (Steindachner). Comparative Biochemistry and Physiology, 105C, 213-217.

Ali, M.T., Babiker, R.B., Tibin, M.I. (1992). Body weight characteristics, yield indices and proximate chemical composition of commercial fish species of Lake Nubia. Journal of Food Science, 46, 58-61.

Ayoade, A.A., Ikulala A.O.O. (2007). Length-weight relationship, condition factor and stomach contents of Hemichromis bimaculatus, Sarotherodon melanotheron and Chromidotilapia guenteri (Perciformes: Cichlidae) in Eleiyele Lake, Southwestern Nigeria, $R e$ vista Biologia Tropical, 55(3-4), 969-977.

Block-Schneider, F.S. (1801). Descriptions of animalian kingdom (Citedfrom Boulenger, 1907). Cross HR, Berry BW. ISBN 22398736597.

El Tay, N.O. (1994). Chemical composition and quality grading of three fish species as related to environmental conditions in the Blue Nile and White Nile. M.Sc. Thesis United Kingdom.

Eyo, A.A. (1991). Carcass composition and filleting yield of ten fish species from Kainji Lake. FAO Fisheries Report FIIU/R467 Suppl. Accra, Ghana. 22-25 Oct.

Fafioye, O.O., Oluajo, O.A. (2005). Length-weight relationship of five fish species in Epe lagoon, Nigeria. African Journal of Biotechnology, 4(7), 749-751.

FAO (1985). Aquaculture statistical data. ADCP, Rome: Food and Agriculture Organization.

Ikomi, R.B., Odum, O. (1998). Studies on aspect of the ecology of the catfish Chrysichthys auratus Geoffrey St. Hilaire (Osteichthyes; Bagridae $\}$ in the River Benue (Niger Delta, Nigeria). Journal of Fisheries Resources, 35(3), 209-218.
Ikongbeh, O.A., Ogbe, F.G., Solomon, S.G. (2012a). Length-weight relationship and condition factor of Chrysichthyes nigrodigitatus from Lake Akata, Benue State, Nigeria. Nigerian Journal of Fisheries, 9(1), 1117.

Ikongbeh, O.A., Ogbe, F.G., Solomon, S.G. (2012b). Length-weight relationship and condition factor of Bagrus docmac from Lake Akata, Benue State, Nigeria. Journal of Animal and Plant Science, 15(3), 2012b, 2267-2274.

Olufeagba, O., Okomoda, V.T. (2015). Preliminary Report on Genetic Improvement of Heterobranchus longifilis through Intraspecific Hybridization of Different strains from Nigeria. Journal of Aquaculture Engineering and Fisheries Research, 1(1), 45-48.

Oniye, J.S., Adebote, D.E., Usma, S.K., Makpo, J.K. (2006). Some aspect of the biology of Protopterus annectens in Jachi Dam near Katsina, Katsina State Nigeria. Journal of Fisheries and Aquatic Science, 1(2), 136-141.

Layèyè, P.A. (2006). Length-weight and length-length relationships of fishes from the Ouèmè River in Benin (West Africa). Journal of Applied Ichthyology, 22, 330333.

Shinkafi, B.A., Ipinjolu, J.K. (2010). Morphometric relationships and relative condition factor of Auchenoglanis occidentalis (Cuvier and Valenciennes) from River Rima, North-western Nigeria, Journal of Fisheries International, 5(4), 61-66.

Solomon, S.G., Okomoda, V.T., Ogbenyikwu, A.I. (2015). Intraspecific morphological variation between cultured and wild Clarias gariepinus (Burchell) (Clariidae, Siluriformes). Archives of Polish Fisheries, 23, 53-61.

Solomon, S.G., Akogu, C.C. (2005). Filleting yields, carcass and nutritional composition of ten freshwater fish species from River Benue, Nigeria. Journal of Agric Science and Technology, 15(1-2), 41-45.

Venu, T.J., Kurup, B.M. (2003). Length-weight relationship of some deep sea fish inhabiting the continental slope beyond 250 depths along the West Coast of India. Naga. Conference proceedings. [International 
Center for Living Aquatic Resources Management 26(2), 17-21.

Youson, J.H., Holmes, J.A., Guchardi, J.A., Seelye, J.G., Beaver, R.E., Gersmehl, J.E., Sower, S.A., Beamish,
F.W.H. (1998). Importance of condition factor and the influence of water temperature and photoperiod on metamorphosis of sea lamprey, Petromyzon marinus. Canadian Journal of Fish and Aquatic Science, 50, 2448-2456. 